\title{
PENENTUAN BAKTERI SULFAT REDUCING BACTERIA (SRB) DAN SULFUR OXIDAZING BACTERIA (SOB) DENGAN MENGGUNAKAN PELARUT YANG BERBEDA
}

\author{
Nurjanna dan Ahmadirrahman Fajrihanif \\ Balai Riset Perikanan Budidaya Air Payau \\ Jl. Makmur Dg. Sitakka 129, Maros, Sulawesi Selatan 90512 \\ E-mail: nugri@yahoo.com
}

\section{ABSTRAK}

Pengamatan ini bertujuan untuk mengetahui populasi bakteri pereduksi sulfat dan pengoksidasi sulfur pada sedimen tambak menggunakan larutan pengencer yang berbeda. Sampel sedimen sebanyak $5 \mathrm{~g}$ digerus dengan lumpang penggerus yang steril hingga homogen. Dua jenis larutan pengencer yang steril yaitu larutan garam fisiologis $(\mathrm{NaCl} 0,85 \% 9 \mathrm{~mL}$ dan larutan Artificial Sea Water (ASW) atau larutan air laut buatan $9 \mathrm{~mL}$ disiapkan. Selanjutnya masing-masing $1 \mathrm{~g}$ sedimen tambak yang telah homogen dimasukkan ke dalam larutan pengencer tersebut, kemudian divortex hingga homogen. Setelah homogen masing-masing diambil $100 \mu \mathrm{L}$, kemudian dimasukkan dalam media penumbuh bakteri SRB dan SOB dalam microplate 24 lubang yang telah disiapkan sebelumnaya. Biakan tersebut kemudian diinkubasi secara Anaerobik selama 12 hari untuk bakteri SRB dan 14 hari untuk SOB. Pengamatan populasi bakteri SRB dilakukan dengan melihat adanya perubahan warna media dari warna merah muda menjadi warna hitam, sedangkan bakteri SOB dapat dilihat dengan adanya perubahan dari warna biru muda menjadi merah bata setelah penambahan larutan kalium iodid (larutan $\mathrm{KI}$ 1\% sebanyak $1 \mathrm{~mL} /$ lubang microplate. Hasil percobaan menunjukkan bahwa populasi bakteri SRB dengan menggunakan pelarut ASW dan garam fisiologis relatif sama terutama pada percobaan periode II dan IV. Sedangkan populasi bakteri SOB relatif lebih tinggi pada penggunaan pelarut garam fisiologis ( $\mathrm{NaCl} 0,85 \%)$ dibanding pelarut ASW.

KATAKUNCl: sulfat reducing bacteria, sulfur oxidazing bacteria, pelarut garam

\section{PENDAHULUAN}

Populasi bakteri secara umum digunakan untuk bakteri dan mikroorganisme lain dan biasanya mengacu pada perubahan di dalam hasil panel sel dan bukan perubahan individu organisme. Pertumbuhan menyatakan pertambahan jumlah atau massa melebihi inokulum asalnya selama bakteri dalam fase pertumbuhan seimbang. beberapa yang mempengaruhi pertumbuhan bakteri antara suhu, lingkungan, gas, dan pH faktor-faktor fisik utama faktor-faktor tersebut harus dipertimbangkan di dalam penyediaan kondisi optimum bagi pertumbuhan kebanyakan spesies bakteri (Michael et al., 1986).

Bakteri sulfat reducing bacteria (SRB) merupakan bakteri anaerob dan hasil akhir oksidasinya menghasilkan asam sulfida $\left(\mathrm{H}_{2} \mathrm{~S}\right)$ yang menyebabkan lumpur menjadi berwarna hitam, di mana $\mathrm{H}_{2} \mathrm{~S}$ sangat beracun bagi ikan dan udang yang dibudidayakan sedang bakteri sulfur oxidazing bacteria (SOB) merupakan bakteri aerob dan menggunakan $\mathrm{H}_{2} \mathrm{~S}$ sebagai elektron aseptor (Gunarto et al., 2008).

Penentuan populasi bakteri dalam satu jenis sampel sangat ditentukan oleh media yang digunakan, selain itu, larutan pengencer atau pelarut yang digunakan juga menentukan keakuratan data populasi dari satu jenis sampel. Penentuan populasi bakteri SRB dapat dilakukan menggunakan media Battersby's sedang untuk SOB digunakan enrichment media (Muir \& Owens, 1996). Sedangkan untuk larutan pengencer digunakan pelarut Artifical Sea Water (ASW) yang terdiri atas ramuan beberapa senyawa garam dan pengencer larutan fisiologis 0,85\% $(\mathrm{NaCl})$ yang sangat mempengaruhi pertumbuhan bakteri. Selain ASW jenis pelarut atau larutan pengencer yang sering digunakan adalah larutan garam fisiologis $(\mathrm{NaCl}$ $0,85 \%$. Dalam penyiapannya larutan garam fisiologis jauh lebih mudah dan sederhana, selain itu lebih ekonomis dibanding ASW. Oleh karena itu, dicoba membandingkan populasi bakteri SRB dan SOB menggunakan kedua larutan pengencer tersebut. 


\section{BAHAN DAN TATA CARA}

\section{BAHAN}

Bahan yang digunakan meliputi: $\mathrm{NaCl}, \mathrm{KCL}, \mathrm{Na}_{2} \mathrm{SO} 4$, $\mathrm{MgCl}_{2} \cdot 6 \mathrm{H}_{2} \mathrm{O}, \mathrm{CaCl}_{2} \cdot 2 \mathrm{H}_{2} \mathrm{O}, \mathrm{FeSO} 4, \mathrm{NH} 4 \mathrm{Cl}, \mathrm{KH}_{2} \mathrm{PO} 4$, Bacto CasAmino Acid, Rezazaurin, air laut, KNO3,NaHCO3, $\mathrm{Na}_{2} \mathrm{~S}_{2} \mathrm{O} 3.5 \mathrm{H}_{2} \mathrm{O}$, Trace metal sulution, alkohol 70\% kapas, biakan bakteri pseudomonas, Nutrien Broth (NB).

\section{ALAT}

Alat yang digunakan meliputi: microplate 24 lubang (well), pipet skala $10 \mathrm{~mL}$ mikro, pipet multi channel, 100 mikron, Bunsen, tip kuning, cawan petri, bunsen, erlemeyer, timbangan analitik, pH meter, cleanbench, shaker, autoclove, jarum ose.

\section{TATA CARA}

\section{Persiapan Media}

- Pembuatan media tumbuh Nutrien Broth (NB)

Timbang NB sebanyak $0,8 \mathrm{~g}$ tambahkan $1,5 \% \mathrm{NaCl}$ larutkan dengan $100 \mathrm{~mL}$ aquadest. Sterilkan dalam autoclove dengan suhu $121^{\circ} \mathrm{C}, 1 \mathrm{Atm}$, selama 15 menit matikan dan keluarkan.

- Pembuatan Media Tryptic Soy Agar (TSA)

Timbang TSA sebanyak $4 \mathrm{~g}$, tambahkan 1,5\% $\mathrm{NaCl}$, larutkan dengan $100 \mathrm{~mL}$ aquadest, panaskan di atas hotplate sambil diaduk dengan menggunakan stirrer. Setelah media larut dan bening angkat dan sterilkan dalam autoclove dengan suhu $121^{\circ} \mathrm{C}, 1 \mathrm{Atm}$, selama 15 menit, matikan dan keluarkan.

\section{- Pembuatan Media Sulfat Reducing Bacteria (SRB)}

Untuk membuat media SRB sebanyak $1.000 \mathrm{~mL}$


$\mathrm{KH}_{2} \mathrm{PO} 4,0,2 \mathrm{~g}$, Bacto cas Amino Acid 1g, ascorbit acid $1 \mathrm{~g}$, lactic Acid $3 \mathrm{~mL}$, rezazaurin $0,001 \mathrm{~g}$, larutkan dengan $500 \mathrm{~mL}$ air laut steril yangbersalinitas 28-30 ppt, dan aquadest $500 \mathrm{~mL}$ atur pHnya sampai 7,5 sterilkan dalam autoclove dengan suhu $121^{\circ} \mathrm{C}, 1 \mathrm{Atm}$, selama 15 menit, matikan dan keluarkan.

- Pembuatan Media Sulfur Oxidazing Bacteria (SOB) Untuk membuat media SOB sebanyak $1.000 \mathrm{~mL}$ ditimbang $\mathrm{KNO} 32,0 \mathrm{~g}, \mathrm{NH} 4 \mathrm{Cl} 1,0 \mathrm{~g}, \mathrm{KH}_{2} \mathrm{PO} 42,0 \mathrm{~g}$, $\mathrm{NaHCO} 32,0 \mathrm{~g}, \mathrm{Na}_{2} \mathrm{~S}_{2} \mathrm{O} 3.5 \mathrm{H}_{2} \mathrm{O} 5,0 \mathrm{~g}$, Trace Metal Solution $1 \mathrm{~mL}$, Resazaurin $0,001 \mathrm{~g}$, air laut $500 \mathrm{~mL}$ salinitas 28-30 ppt, aquadest $500 \mathrm{~mL}$ ukur pH 6,8-7,0 sterilkan dalam autoclove dengan suhu $121^{\circ} \mathrm{C}, 1 \mathrm{Atm}$ selama 15 menit matikan dan keluarkan.
- Pembuatan Stok Larutan Artifical Sea Water (ASW) Untuk membuat larutan stok ASW sebanyak 1.000 $\mathrm{mL}$ maka ditimbang $\mathrm{NaCl} 26,35 \mathrm{~g}, \mathrm{KCl} 1,125 \mathrm{~g}, \mathrm{Na}_{2} \mathrm{SO} 4$ $0,428 \mathrm{~g}, \mathrm{MgCl}_{2} .6 \mathrm{H}_{2} \mathrm{O} 7,62 \mathrm{~g}, \mathrm{CaCl}_{2} \cdot 2 \mathrm{H}_{2} \mathrm{O} 0,218 \mathrm{~g}$, larutkan dengan $1.000 \mathrm{~mL}$ aquadest steril.

- Pembuatan Larutan Garam Fisiologis ( $\mathrm{NaCl} 0,85 \%$ Untuk membuat larutan $\mathrm{NaCl} 1.000 \mathrm{~mL}$, timbang $\mathrm{NaCl}$ 8,5 g larutkan dengan $1.000 \mathrm{~mL}$ aquadest steril.

- Peremajaan Bakteri Pseudomonas sp.

Stok bakteri diremajakan dengan menginokulasi pada media TSA dalam cawan petri secara aseptik diinkubasi dalam inkubator suhu $28^{\circ} \mathrm{C}-30^{\circ} \mathrm{C}$ selama 24-48 jam, biakan dipindahkan secara aseptik kedalam larutan NB, homogenkan sambil diseker selama 12 jam untuk memperbanyak sel bakteri dalam larutan.

\section{Cara Menginokulasi Sampel}

Sampel tanah dari lapangan ditimbang sebanyak $1 \mathrm{~g}$ masukkan ke dalam larutan ASW volume $9 \mathrm{~mL}$ dan larutan garam fisiologis volume $9 \mathrm{~mL}$. M edia SRB dan media SOB dipipet ke dalam masing-masing lubang microplate sebanyak $2 \mathrm{~mL}$ tiap lubang. Media SRB sebelum diinokulasi sampel sebelumnya ditambahkan dengan bakteri Pseudomonas sp. sebanyak $50 \mu \mathrm{L}$ inkubasi selama 1 jam, setelah itu, media tersebut diinokulasi sampel sedimen yang sudah dilarutkan sebayak $100 \mu \mathrm{L}$ dari masing pelarut yang berbeda, seterusnya diencerkan bertingkat sesuai dengan jumlah well pada microplate. Selanjutnya diinkubasi pada wadah kedap udara dengan menggunakan gas generating. Inkubasi selama 12 sampai 14 hari. Pengamatan populasi bakteri untuk SRB dilihat dari adanya endapan berwarna hitam pada dasar microplate. Sedang untuk pengamatan SOB populasi bakteri dapat diketahui dari penambahan larutan kalium jodida sebanyak $1 \mathrm{~mL}$ apabila larutan berubah menjadi kuning berarti positif.

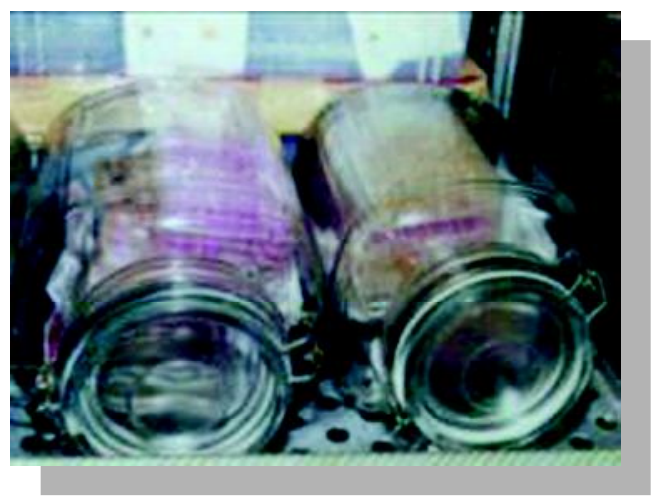

Inkubasi Media SRB dan SOB 


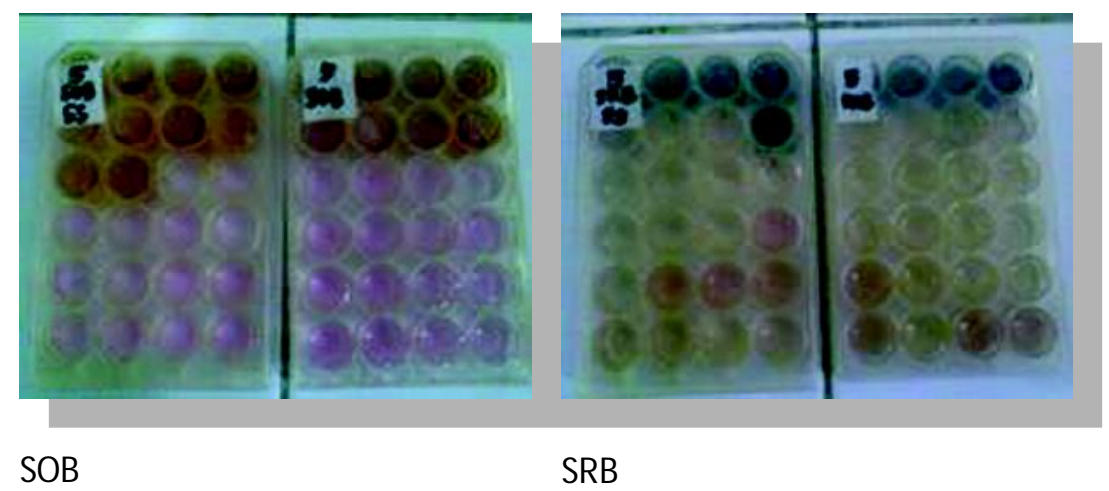

Dari hasil perubahan SRB dan SOB populasi masing-masing dapat diketahui dengan menghitung metode MPN (Muir \& Owns, 1996).

\section{HASIL DAN BAHASAN}

Dari hasil yang didapatkan dengan menggunakan pelarut yang berbeda dapat dilihat pada Gambar 1 .

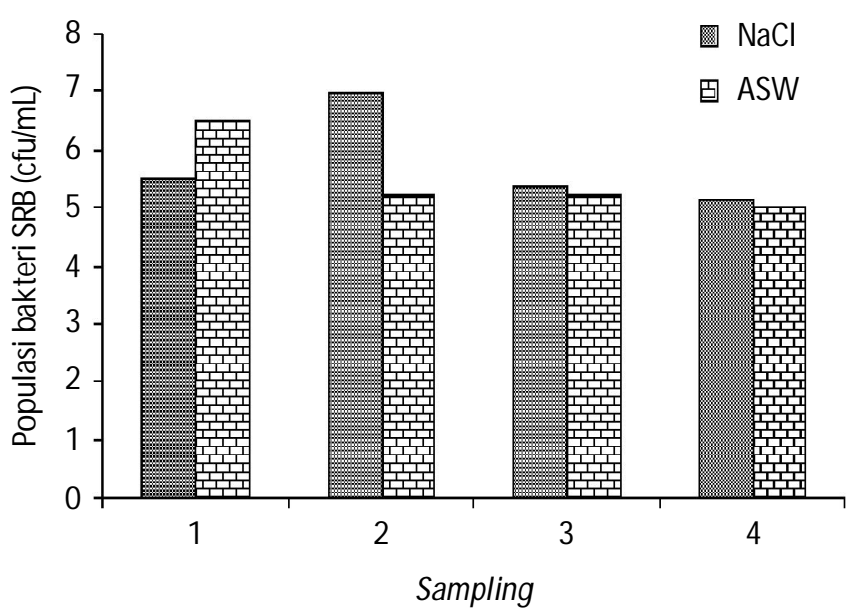

Gambar 1. Populasi bakteri sulfat reducing bacteria (SRB) dengan menggunakan pelarut yang berbeda ( $\mathrm{NaCl}$ dan ASW)

Pada Gambar 1 terlihat bahwa dengan menggunakan media pelarut ASW pada percobaan periode pertama populasi bakteri lebih tinggi dibandingkan dengan menggunakan pelarut garam fisiologis, sedangkan pada periode kedua populasi bakteri SRB pada pelarut garam fisiologis lebih tinggi dibanding menggunakan pelarut ASW. Pada percobaan periode ketiga dan keempat populasi bakteri cenderung sama pada pelarut $\mathrm{NaCl}$ dan pelarut ASW, sehingga dari kedua pelarut ini dapat digunakan dalam penentuan populasi bakteri SRB .

Pada Gambar 2 terlihat bahwa dalam penentuan populasi SOB dengan menggunakan pelarut yang berbeda terlihat bahwa dengan menggunakan larutan garam

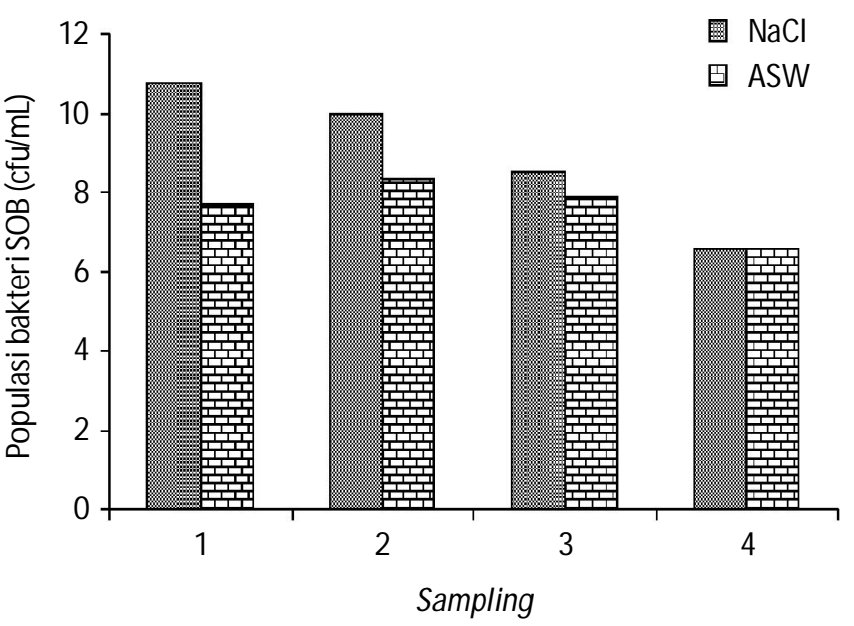

Gambar 2. Populasi bakteri sulfur oxidazing bacteria (SOB) dengan menggunakan pelarut yang berbeda $(\mathrm{NaCl}$ dan ASW)

fisiologis populasi bakteri SOB lebih tinggi dibanding menggunakan pelarut ASW. Hal ini menunjukkan bahwa pelarut ASW lebih cepat digunakan dalam penentuan populasi SOB dari satu jenis sampel.

\section{KESIMPULAN}

Untuk menentukan populasi bakteri SRB dapat digunakan pelarut ASW dan garam fisiologis, sedangkan untuk menentukan populasi bakteri SOB lebih cocok digunakan pelarut garam fisiologis.

\section{DAFTAR ACUAN}

Gunarto. 2006. Apakah Nilai Reduksi dan Oksidasi Potensial Sedimen Tambak Berpengaruh Terhadap Produksi Udang Windu di Tambak. M edia Akuakultur, 1(3): 91-96.

Muir, P. \& Owns, L. 1996. Sampling For Sulphure cycle bacteria of sediment. Departement of Microbiology Biomedical and Tropical Veterinary Sciences. James Cook University of North Queensland, Australia, 7 pp. 
Media Akuakultur Volume 5 Nomor 1 Tahun 2010

Michael J. Pelczar, Jr. \& chan, E.C.S. 1986. Dasar-Dasar Microbiologi. Diterjemahkan Oleh Hadioetomo, R.S., Imas, S.T., Tjitrosomo, S., \& Lestari, S. Angka. Penerbit Universitas Indonesia (UI-Press) Jakarta. 